\title{
Socio-economic Factors and Residents' Health in Nigeria Urban Centres
}

\author{
Olawuni, P.O.
}

\begin{abstract}
This paper examined the various socio-economic attributes (average income, educational attainment, occupation and household size) among the low, medium and high income earners in Osogbo, Osun State, Nigeria. It also assessed the effects of these socio-economic attributes on the health of residents with a view to determining the implications that socio- economic attributes have on the environmental related ill health on households (diarrhoea, vomiting, stomache ache, typoid and malaria) in the study area. Having divided Osogbo township map into equal grids, using Geographic Information System (GIS) and systematically sampled 432 household heads, the data collected is subjected to simple statistical analysis. The study revealed that incidence of ill heath especially malaria is prevalent among the working age group (20-50) years. In addition, respondents with secondary education and below have higher incidence of ill health than those that attained below university and university education. Respondents that engaged in business, petty trading and artisan jobs have higher incidence of ill health than civil servants and farmers. Also respondents that earned below \#400000/annum have higher incidence of ill heath than those that earned above \#400000/annum.The study then suggested the introduction of standard yardstick policy, which could be used to measure socio-economic status of residents in relation to their health status determinants in this country.
\end{abstract}

\section{Introduction}

Socio-economic inequalities in health are persistent, widespread, and widening. The lower the individual's position on the socio-economic hierarchy, the worse their health status, whether measured by life expectancy, disability, or self-reported wellbeing (Kawachi, 1998). 
Most studies that have investigated variations in health within cities recognised that individual socio-demographic characteristics are important in determining a person's chances of having poor health rather than residential areas. For example, Pocock et al (1987), noted that people in lower social classes experience ill health at higher rates, not minding where they are residing. Another researcher, Bartley, 1994 shared the same view, when he identified unemployment as part of the variables, contributing to higher rates of ill health in the city no matter where you are residing. Waters and Suhrcke (2005), in their study on socio-economic inequalities in health and health care access in Central and Eastern Europe and the Commonwealth of Independent States (CIS) found out among others that incidence of poverty across regions was more strongly related to male than female life expectancy in Russia. In another study on risky health behaviour such as smoking in Russia, Carlson 2001, found associations with smoking and economic deprivation in childhood. In addition, Malyntina et al, (2004) discovered from their cohort study (based on the Novosibirsk MONICA Project) in Russia, that there existed associations between socio-economic status and cardiovascular mortality. Using educational status as a criterion, the authors found that the age-adjusted relative risk from cardiovascular disease was greater among less educated people. Also, Sumskas, et al. (2002) from their epidemiological investigation among Lithuania School-aged children indicated that there exist differences in health status among socio-economic groups. It was equally demonstrated that people from lower socio-economic groups are less healthy than people from more affluent groups. Guerrant et al (1983), in their study, used poverty level and housing facilities in Dacatuba, Brazil, and noted that rates of diarrhoea infections were significantly higher in poor urban and poor rural areas than the non-poor central urban area.

There are still other works, which have shown increasing evidence of certain characteristics of the area in which individual lives as having significant roles to play in mediating between individual levels of relationship. Shouls et al (1997), Congdon et al (1997) Hann et al 
(1987), Gould and Jones (1996) and Ellaway and Macintyre (1987) have all found area of residence and individual characteristics to be independently related to health. The influences of area on an individual's health are usually referred to as 'area effect'. Such effects like alienation, sense of belonging, social class, employment, areas liable to flooding among others.

Lenz, (1988), measured the prevalence of malaria and diarrhoea in Jakarta Indonesia, using three (3) areas of classified risk factors; socio-economic, mobility and environmental. He discovered that only environmental variable is associated with malaria and diarrhoea in the study area. Such environmental variables as crowded environment, bathing place, drinking water source and storage, housing environment among others were highlighted. Majority of the above reviewed works were carried out in countries that were relatively more organised and developed, unlike a developing country like Nigeria, especially Osogbo, the capital city of Osun State, where emphasis on specific socio-economic variables like educational attainment, occupation and average income among others in relation to households' health have not been addressed.

Using Osogbo as case study, this study aims at identifying those socio-economic variables that have effects on the health of residents in the study area. It also attempts to evaluate the degree of relationship between socio-economic variable and environmental related health problems in the area.

\section{Study Area}

Usually, the economy of a town is determined by the nature of its physical development, its historical background and the consequences of administration and political decisions. Osogbo is no exemption. Before the $20^{\text {th }}$ century, the main economic activities in the town were farming, trading, carving, and dyeing, weaving and blacksmithing. Because of its location, the town benefits from the production of forest and savanna crop. The major cash crops grown include cotton (savanna crop), cocoa, kolanut and oil-palm (forest crops), while the 
main subsistence crops include yam, cassava, banana, citrus and cocoyam. Subsistence crops are grown close to the town while cash crops are grown farther away from the town. The arrival of Europeans in pre-dependence Nigeria and thereafter had a great economic impact on Osogbo and her socio-economic development. It was not surprising, therefore, that virtually all the big names in trading, United African Company (UAC), G.B Ollivant, John Holt, Patterson Zochonis (PZ), Lennards Shoe Company, Bata; the British Cotton Growing association (BCGA), have branches in Osogbo, but, the introduction of Structural Adjusted Programme (SAP) forced the closure of many of these industries which has equally reduced many people to unemployed residents status. Also, the ever increasing rate of inflation in Nigeria has forced many Nigerian especially Osogbo residents into the groups of 'haves' and have-nots'. This has equally divided them to various socio-economic classes, that is, low, medium and high income earners. This study then takes a look into the effects of these socio-economic strata on the health of residents in the study area.

\section{Methodology}

Analogue based map of Osogbo was converted into digital format. Materials required include: Global Positioning System (GPS), Osogbo base map/Aerial Photograph, Personal Computer, Digitizing table, Scanner and Printer. Primary data were collected through the structured questionnaire, administered on 432 household heads in the three residential density zones in Osogbo. Variables examined include: socio-economic variables and health conditions. Since households are the targets of the data source for this work, point data $(\mathrm{x}, \mathrm{y})$ was adopted. To be able to precisely locate these points in space and on the map, the map was divided into equal grids. This is referred to as cell method or fixed grid method (Samet, 1990a). Samet used this method to locate eight North American cities in 1990. The same method was used to locate each of the sampled households represented 
by a dot or point on the map in the study area. Having divided the study area into equal grids, one out of every ten grids was selected, and at least $10 \%$ of the households in each of the selected grids were sampled through a systematic random sampling technique. Information collected from the questionnaire formed the attribute data or table to the already digitized point data. These were used to run simple statistical analysis (cross tabulation and chi square), because the data collected for the study is categorical and ordinal in nature. In addition, environmental related health problems that appeared very pronounced from the data analysis were considered for discussion.

\section{Discussion and Findings}

In this analysis, relevant variables within socio-economic fabrics like average age, educational attainment, occupation, average income and household size were considered along with ill health issues like diarrhoea, vomiting, stomach ache, typhoid and malaria. It is worth noting that only ill health issues that were very significant in the analysis were also considered for discussion in this study.

Table 1 indicates the relationships that exist between average age of respondents and ill health in Osogbo Township. The table showed that $32.4 \%$ of the respondents between $20-40$ years of age had malaria, $14.1 \%$ (stomach ache), 8.2 (diarrhoea), 4.3 (typhoid) and $3.8 \%$ vomited. Among respondents between the ages of 41 years to 60 years, $20.1 \%$ had malaria, 6.3 (stomach ache), 3.6 (diarrhoea. 1.8. (Vomiting) and 1.0 (typhoid). The table further revealed that the incidence of malaria (32.4\%), stomach ache (14.1\%) and diarrhoea $(8.2 \%)$ were more prominent among respondents between the ages of 20 to 40 years in Osogbo. The implication of the above table is that though, malaria incidence was generally high in the study area, it was more pronounced among the working age group. It is unlikely that the 
pursuit for socio-economic advancement by people between age 20 to 50years led to the outcome of malaria incidences, as revealed by the table.

Table 2 showed that among 32.2\% of respondent with Secondary School education, $15.6 \%$ had malaria, 8.3\% (Stomach ache), 4.4\% (Diarrhoea) and $2.1 \%$ (typhoid). Among $38.0 \%$ respondents with both below University and University education, $24.1 \%$ had malaria (This was probably because majority of the respondents attached various types of illness to malaria; more so educational attainment had nothing to do with malaria incidence), $7.9 \%$ had stomach ache, 3.2\% (Diarrhoea) and $0.8 \%$ vomiting. $15.6 \%$ of respondent with primary and no formal education had malaria, 5.2\% (stomach ache), 5.0\% (Diarrhoea) and $2.7 \%$ vomiting. It should be noted that respondents with secondary education had the highest ill health incidences (32.2) followed by respondents below university education (20.7), which meant that these category of respondents are probably unskilled and engaged in different types of menial jobs, thereby encountering malaria especially, in the course of their search for daily needs. Also, access to regular medical check-up may be lacking among these category of people, coupled with financial incapacity.

Table 3 indicated the relationship between occupation and ill health in Osogbo. Among $17.5 \%$ of the Civil Servants, $12.3 \%$ had malaria, $2.7 \%$ (stomach ache), $1.7 \%$ (diarrhoea). Out of $29.7 \%$ businessmen and women, $16.2 \%$ had malaria, $7.5 \%$ (stomach ache), $3.1 \%$ (diarrhoea) and $1.7 \%$ (typhoid). Among $7.1 \%$ of the respondents that are farmers, $2.9 \%$ had malaria, and $1.2 \%$ each has diarrhoea and vomited. $19.8 \%$ of the respondents were petty traders and $10.7 \%$ of them had malaria, $4.6 \%$ (stomach ache), $2.9 \%$ (diarrhoea) and $1.5 \%$ (vomiting). Among 26.0\% of the artisan, 13.7\% had malaria, 6.0\% had stomach ache, $3.1 \%$ (diarrhoea) and $2.1 \%$ (typhoid). Perhaps the relationships that existed in the percentages of ill health occurrences on the above table revealed that, the type of occupational activities engaged by respondents had to do with various ill health incidences in 
the study area. In essence, respondents that engaged in civil service work, that has just eight hours to work in a day may not complain of malaria like others who engaged in private business, and have no specific numbers of hours to work in a day. This is because a person, who is self employed and probably unskilled, will work very hard among others, to secure maximum profit and be able to care for his/her household's members' health and other domestic needs.

Table 4 showed the relationship between average income of respondent and ill health in Osogbo. The table showed that $36.5 \%$ of the respondents earned below $\$ 200,000.00$ annually and out of this number, $16.9 \%$ had malaria, $8.9 \%$ (stomach ache) and $6.8 \%$ (diarrhoea). Among $41.1 \%$ of the respondents that earned between $\$ 200,000.00$ and $\$ 400,000.00$, annually, $23.3 \%$ had malaria, $7.8 \%$ had stomach ache and $5.1 \%$ had diarrhoea. $22.1 \%$ of the respondents are with $\$ 400,000.00$ and above annual income and $14.9 \%$ had malaria, $4.9 \%$ (stomach ache) and $1.2 \%$ (typhoid). The table further revealed that respondents that earned less than N300, 000.00 per annum formed the majority and were more prone to incidence of ill health in the study area. The chi square test $\left(\mathrm{X}^{2}=36.681 ; \mathrm{P}=0.002\right)$ shows that there was a significant relationship between average income and ill health in Osogbo. From the above discussion and chi square result, it could be seen that income had a strong relationship with respondents' health and that, respondents in the high income group experienced less ill health incidence than their low income counterparts, because, people in the high income group have the financial capability of taking care of their health. On the other hand people in the low income category may not have enough financial bases to take adequate care of their household members' health.

Table 5 showed the relationship between household size and ill health in Osogbo. The table showed that out of $36.9 \%$ of the respondents with less than five (5) persons in the household, $21.7 \%$ had malaria, $7.4 \%$ (stomach ache), $3.5 \%$ (diarrhoea) and $2.5 \%$ (vomiting). Among $63.1 \%$ of the respondents with more than five (5) persons in the household, $33.9 \%$ had malaria, $14.3 \%$ (stomach ache) and $8.7 \%$ 
(diarrhoea), 3.3\% (typhoid) and 3.1\% (vomiting). It was observed that respondents with more than 2 persons in the household have higher percentage of ill health than respondents with just 1 person in the household. Which then means that the higher the number of people in a household the more likely the incidence of ill health in the study area.

\section{Conclusion}

This study has examined differences in socio-economic characteristics of residents and the attending incidences of environmental related ill health in the study area. Socio-economic factors considered for this work include: average age, educational attainment, occupation, average income and household size, along with key reported environmental related ill health like, diarrhoea, vomiting, stomach ache, typhoid and malaria. The study revealed that incidence of ill health; especially malaria is prevalent among the working age group (20-50 years). It is likely that people in this category are in the habit of engaging themselves on daily activities that will earn them and their households' livelihood. Also, respondents with secondary school education and below have higher incidences of ill health than those that attained below university and university education. In addition, respondents that engaged in business, petty trding and artisan jobs have higher incidence of ill health than those civil servants and farmers. On average income, the study revealed that respondents that earned below N400, 000.00 per annum have higher incidence of ill health than those that earned above N400, 000.00 per annum. Equally, households with more than 2 persons have higher incidence of ill health than households with just one person.

The trend revealed by this study was that, those respondents within the working age group that have higher incidence of ill health, probably fall into the category of respondents with secondary education and below, and at the same time engaged in business, petty trading and artisan and earned below N400, 000.00 per annum, also with more than 2 persons in the households. This tends to support the assertion of authors like Pocock et al (1987), Waters and Suhrcke 
(2005) and Malyntina et al (2004) among others, who from their various studies found strong associations between socio-economic factors and ill health.

It is however argued that each of the socio-economic variables used here is used in isolation with the ill health incidences. This is not enough to determine the health of residents, but, the hindrance is that there is presently no standard yardstick to measure socio-economic status in this country. Although, income has relationship with ill health of respondents, it is likely associated with variables such as educational attainment and occupation, among others. It is then suggested that standard yardstick to measure socio-economic status be put in place in this country. This could be in terms of position in the place of work (if civil servant - Grade Level), educational status (minimum level should be established), unfalsified average annual income should be specified, coupled with minimum living standard. This is in relation to affordability of three square meals per day for the household, personal and family health care, standard accommodation and mobility among others.

Above all, effort should be geared towards making life easy for people in terms of government's subsidy on most of infrastructural and social facilities. Also, arrangement should be made for unemployed people to have access to daily food and health care services. This will in no small measure improve the well-being and health status of the residents in the study area and other residents in other parts of the country. 


\section{References}

Bartley, M. (1994): Unemployment and Ill Health - Understanding The Relationship. Journal of Epidemiology and Community Health, Vol. 46, No. 4,pp.333-337.

Carlson, P. (2001): Risk Behaviours and Self-rated Health in Russua. Journal of Epidemiology and Community Health, 55: 806817.

Congdon, P., Shouls, S., Curtis, S. (1997): A Multilevel Perspective on Small-Area Health and Mortality: A Case Study of England and Wales. International Journal of Population Geography, Vol. 3, pp. 243-263.

Ellaway, A., Macintyre, S. (1987): Does Where You Live Predict Health Related Behaviours? A Case Study in Glasgow. Health Bulletin, Vol. 54, No. 6, pp.443-446.

Gould, M., Jones, K. (1996): Analysing Perceived Limiting LongTerm Illness: A question of Where You Live or Who You Are? L S Working Paper No. 77, SSRU: City University. Hutchinson and Co. Ltd.

Hann, M., Kaplan, G., Camacho, T. (1987): Poverty and Health Prospective Evidence From The Alameda County Study. American Journal of Epidemiology, Vol. 126 No. 6 pp.989998.

Sumskas, L and Zaborskis, A.: Socio-economic Differenes in health behaviours Among Lithuanian School-aged Children: Results from 1994-1998 surveys. (In Project Financed by WHO PAEECHP, Prepared by: Prof.Zilvinas Padaiga). Department of Preventive Medicine, Kaunas University of Medicine, eiveniu sStr. 4, LT-3007, Kaunas, Lithuania.

Lenz, R. (1988): "Jakarta Kampung Morbidity Variations: Some Policy Implications". Social Science and Medicine 26:641649.

Malyutina, S. et.al. (204): Education, Marital status, and Total and Cardiovascular Mortality in Novosibirsk, Russia: A 
Prospective Cohort Study. Annals of Epidemiology, 214(4): 244-249.

Pocock, S., Shaper, A. and Cook, D. (1987): Social Class Differences in Ischaemic Heart Disease in British Men. Lancet, Vol II, pp. 197-201. pp. 284-289.

Shouls, S., Congdon, P. and Curtis, S. (1997): Geographic Variation in Health: The Development of A Relevant Area Typology for SAR Districts.

Walters, S. and Suhrcke, M. (2005): Socioeconomic Inequalities in Health and Healthcare Access in Central and Eastern Europe and the CIS: A Review of the recent Literature. WHO European Office for Investment for Health and Development; Working Paper 2005/1.

Table: 1 Relationship between Average Age and Ill Health.

\begin{tabular}{|c|c|c|c|c|c|c|c|}
\hline $\begin{array}{l}\text { Average } \\
\text { Age }\end{array}$ & & Diarrhoea & Vomiting & $\begin{array}{l}\text { Stomach } \\
\text { ache }\end{array}$ & Typhoid & Malaria & Total \\
\hline $20-30 y r s$ & $\begin{array}{l}\text { Count } \\
\%\end{array}$ & $\begin{array}{l}19 \\
3.9\end{array}$ & $\begin{array}{l}10 \\
2.0\end{array}$ & $\begin{array}{l}41 \\
8.4\end{array}$ & $\begin{array}{l}15 \\
3.1\end{array}$ & $\begin{array}{l}80 \\
16.3\end{array}$ & $\begin{array}{l}165 \\
33.6\end{array}$ \\
\hline $31-40 y r s$ & $\begin{array}{l}\text { Count } \\
\%\end{array}$ & $\begin{array}{l}21 \\
4.3\end{array}$ & $\begin{array}{l}9 \\
6.3\end{array}$ & $\begin{array}{l}28 \\
5.7\end{array}$ & $\begin{array}{l}6 \\
1.2\end{array}$ & $\begin{array}{l}79 \\
16.1\end{array}$ & $\begin{array}{l}143 \\
29.1\end{array}$ \\
\hline $41-50 y r s$ & $\begin{array}{l}\text { Count } \\
\%\end{array}$ & $\begin{array}{l}10 \\
2.0\end{array}$ & $\begin{array}{l}5 \\
1.0 \\
\end{array}$ & $\begin{array}{l}19 \\
3.9 \\
\end{array}$ & $\begin{array}{l}3 \\
0.6 \\
\end{array}$ & $\begin{array}{l}60 \\
12.2 \\
\end{array}$ & $\begin{array}{l}97 \\
19.8 \\
\end{array}$ \\
\hline $51-60 y r s$ & $\begin{array}{l}\text { Count } \\
\% \\
\end{array}$ & $\begin{array}{l}8 \\
1.6 \\
\end{array}$ & $\begin{array}{l}4 \\
0.8 \\
\end{array}$ & $\begin{array}{l}12 \\
2.4 \\
\end{array}$ & $\begin{array}{l}12 \\
2.4 \\
\end{array}$ & $\begin{array}{l}39 \\
7.9 \\
\end{array}$ & $\begin{array}{l}75 \\
15.3 \\
\end{array}$ \\
\hline $\begin{array}{l}\text { Above } 60 \\
\text { yrs. }\end{array}$ & $\begin{array}{l}\text { Count } \\
\% \\
\end{array}$ & - & - & $\begin{array}{l}3 \\
0.6 \\
\end{array}$ & - & $\begin{array}{l}8 \\
1.6 \\
\end{array}$ & $\begin{array}{l}11 \\
100.0 \\
\end{array}$ \\
\hline Total & $\begin{array}{l}\text { Count } \\
\% \\
\end{array}$ & \begin{tabular}{|l|}
58 \\
11.8 \\
\end{tabular} & $\begin{array}{l}28 \\
5.7\end{array}$ & $\begin{array}{l}103 \\
17.3 \\
\end{array}$ & $\begin{array}{l}26 \\
5.3 \\
\end{array}$ & $\begin{array}{l}266 \\
54.2 \\
\end{array}$ & $\begin{array}{l}491 \\
100.0 \\
\end{array}$ \\
\hline
\end{tabular}

Source: Author's Field Survey, 2006. 
Table 2: Relationship between Educational Attainment and Ill Health

\begin{tabular}{|c|c|c|c|c|c|c|c|}
\hline $\begin{array}{l}\text { Educational } \\
\text { Attainment }\end{array}$ & & Diarrhoea & Vomiting & $\begin{array}{l}\text { Stomach } \\
\text { ache }\end{array}$ & Typhoid & Malaria & Total \\
\hline $\begin{array}{l}\text { No formal } \\
\text { Education }\end{array}$ & $\begin{array}{l}\text { Count } \\
\%\end{array}$ & $\begin{array}{l}9 \\
1.9\end{array}$ & $\begin{array}{l}4 \\
0.8\end{array}$ & $\begin{array}{l}14 \\
2.9\end{array}$ & $\begin{array}{l}5 \\
1.0\end{array}$ & $\begin{array}{l}42 \\
8.7\end{array}$ & $\begin{array}{l}74 \\
15.3\end{array}$ \\
\hline $\begin{array}{l}\text { Primary } \\
\text { School }\end{array}$ & $\begin{array}{l}\text { Count } \\
\%\end{array}$ & $\begin{array}{l}15 \\
3.1\end{array}$ & $\begin{array}{l}9 \\
1.9\end{array}$ & $\begin{array}{l}11 \\
2.3\end{array}$ & $\begin{array}{l}1 \\
0.2\end{array}$ & $\begin{array}{l}33 \\
6.9\end{array}$ & $\begin{array}{l}69 \\
14.3\end{array}$ \\
\hline Secondary & $\begin{array}{l}\text { Count } \\
\% \\
\end{array}$ & $\begin{array}{l}21 \\
4.4 \\
\end{array}$ & $\begin{array}{l}9 \\
1.9 \\
\end{array}$ & $\begin{array}{l}40 \\
8.3 \\
\end{array}$ & $\begin{array}{l}10 \\
2.1 \\
\end{array}$ & $\begin{array}{l}75 \\
15.6 \\
\end{array}$ & $\begin{array}{l}155 \\
32.2 \\
\end{array}$ \\
\hline $\begin{array}{l}\text { Below } \\
\text { University }\end{array}$ & $\begin{array}{l}\text { Count } \\
\%\end{array}$ & $\begin{array}{l}7 \\
1.5\end{array}$ & $\begin{array}{l}2 \\
0.4\end{array}$ & $\begin{array}{l}22 \\
4.6\end{array}$ & $\begin{array}{l}8 \\
1.7\end{array}$ & $\begin{array}{l}61 \\
12.9\end{array}$ & $\begin{array}{l}100 \\
20.7\end{array}$ \\
\hline University & $\begin{array}{l}\text { Count } \\
\%\end{array}$ & $\begin{array}{l}8 \\
1.7\end{array}$ & $\begin{array}{l}2 \\
0.4\end{array}$ & $\begin{array}{l}16 \\
3.3\end{array}$ & $\begin{array}{l}3 \\
0.6\end{array}$ & $\begin{array}{l}54 \\
11.2\end{array}$ & $\begin{array}{l}83 \\
17.3\end{array}$ \\
\hline Total & $\begin{array}{l}\text { Count } \\
\%\end{array}$ & $\begin{array}{l}60 \\
12.5\end{array}$ & $\begin{array}{l}26 \\
5.4\end{array}$ & $\begin{array}{l}103 \\
21.4\end{array}$ & $\begin{array}{l}27 \\
5.6\end{array}$ & $\begin{array}{l}265 \\
55.1\end{array}$ & $\begin{array}{l}481 \\
100.0\end{array}$ \\
\hline
\end{tabular}

Source: Author's Field Survey, 2006.

Table 3: Relationship between Occupation and Ill Health

\begin{tabular}{|c|c|c|c|c|c|c|c|}
\hline Occupation & & Diarrhoea & Vomiting & $\begin{array}{l}\text { Stomach } \\
\text { ache }\end{array}$ & Typhoid & Malaria & Total \\
\hline $\begin{array}{l}\text { Civil } \\
\text { Servant }\end{array}$ & $\begin{array}{l}\text { Count } \\
\%\end{array}$ & $\begin{array}{l}8 \\
1.7 \\
\end{array}$ & $\begin{array}{l}1 \\
0.2 \\
\end{array}$ & $\begin{array}{l}13 \\
2.7 \\
\end{array}$ & $\begin{array}{l}3 \\
0.6 \\
\end{array}$ & $\begin{array}{l}59 \\
12.3 \\
\end{array}$ & $\begin{array}{l}84 \\
17.5 \\
\end{array}$ \\
\hline Business & $\begin{array}{l}\text { Count } \\
\%\end{array}$ & $\begin{array}{l}15 \\
3.1\end{array}$ & $\begin{array}{l}6 \\
1.2\end{array}$ & $\begin{array}{l}36 \\
7.5\end{array}$ & $\begin{array}{l}8 \\
1.7\end{array}$ & $\begin{array}{l}78 \\
16.2\end{array}$ & $\begin{array}{l}143 \\
29.7\end{array}$ \\
\hline Farming & $\begin{array}{l}\text { Count } \\
\%\end{array}$ & $\begin{array}{l}6 \\
1.2\end{array}$ & $\begin{array}{l}6 \\
1.2\end{array}$ & $\begin{array}{l}5 \\
1.0\end{array}$ & $\begin{array}{l}3 \\
0.6\end{array}$ & $\begin{array}{l}14 \\
2.9\end{array}$ & $\begin{array}{l}34 \\
7.1\end{array}$ \\
\hline $\begin{array}{l}\text { Petty } \\
\text { trading }\end{array}$ & $\begin{array}{l}\text { Count } \\
\% \\
\end{array}$ & $\begin{array}{l}14 \\
2.9 \\
\end{array}$ & $\begin{array}{l}7 \\
1.5 \\
\end{array}$ & $\begin{array}{l}22 \\
4.6 \\
\end{array}$ & $\begin{array}{l}3 \\
0.6 \\
\end{array}$ & $\begin{array}{l}49 \\
10.2 \\
\end{array}$ & $\begin{array}{l}95 \\
19.8 \\
\end{array}$ \\
\hline Artisan & $\begin{array}{l}\text { Count } \\
\%\end{array}$ & $\begin{array}{l}15 \\
3.1\end{array}$ & $\begin{array}{l}8 \\
1.7\end{array}$ & $\begin{array}{l}29 \\
6.0\end{array}$ & $\begin{array}{l}10 \\
2.1\end{array}$ & $\begin{array}{l}66 \\
13.7\end{array}$ & $\begin{array}{l}125 \\
26.0\end{array}$ \\
\hline Total & $\begin{array}{l}\text { Count } \\
\%\end{array}$ & $\begin{array}{l}58 \\
12.1\end{array}$ & $\begin{array}{l}28 \\
5.8\end{array}$ & $\begin{array}{l}105 \\
21.8\end{array}$ & $\begin{array}{l}27 \\
5.6\end{array}$ & $\begin{array}{l}266 \\
55.3\end{array}$ & $\begin{array}{l}481 \\
100.0\end{array}$ \\
\hline
\end{tabular}

Source: Author's Field Survey, 2006. 
Olawuni, P.O.

Table 4: Relationship between Average Income and Ill Health

\begin{tabular}{|l|l|l|l|l|l|l|l|}
\hline $\begin{array}{l}\text { Average } \\
\text { Income }\end{array}$ & & Diarrhoea & Vomiting & $\begin{array}{l}\text { Stomach } \\
\text { ache }\end{array}$ & Typhoid & Malaria & Total \\
\hline$<100$ & Count & 16 & 1 & 13 & - & 34 & 64 \\
& $\%$ & 3.3 & 0.2 & 2.7 & - & 7.0 & 13.2 \\
\hline $100-200$ & Count & 17 & 7 & 30 & 9 & 48 & 113 \\
& $\%$ & 3.5 & 1.4 & 6.2 & 1.9 & 9.9 & 23.3 \\
\hline $200-300$ & Count & 18 & 7 & 18 & 8 & 54 & 105 \\
& $\%$ & 3.7 & 1.4 & 3.7 & 1.7 & 11.1 & 22.0 \\
\hline $300-400$ & Count & 7 & 8 & 20 & 2 & 59 & 96 \\
& $\%$ & 1.4 & 1.7 & 4.1 & 0.4 & 12.2 & 19.8 \\
\hline$>400$ & Count & 1 & 4 & 24 & 6 & 72 & 107 \\
& $\%$ & 0.2 & 0.8 & 4.9 & 1.2 & 14.9 & 22.1 \\
\hline Total & Count & 59 & 27 & 105 & 25 & 267 & 485 \\
& $\%$ & 12.2 & 5.6 & 21.6 & 5.2 & 55.1 & 100.0 \\
\hline
\end{tabular}

Source: Author's Field Survey, 2006. $\quad X^{2}=36.681 ; \quad P=0.002$

Table 5: Relationship between Household Size and Ill Heath in Osogbo.

\begin{tabular}{|l|l|l|l|l|l|l|l|}
\hline $\begin{array}{l}\text { Household } \\
\text { Size }\end{array}$ & & Diarrhoea & Vomiting & $\begin{array}{l}\text { Stomach } \\
\text { ache }\end{array}$ & Typhoid & Malaria & Total \\
\hline 1 Person & $\begin{array}{l}\text { Count } \\
\%\end{array}$ & 2 & 2 & 3 & 2 & 11 & 20 \\
& 0.4 & 0.4 & 0.6 & 0.4 & 2.3 & 4.1 \\
\hline 2-4 persons & Count & 15 & 10 & 33 & 7 & 94 & 159 \\
& $\%$ & 3.1 & 2.1 & 6.8 & 1.4 & 19.4 & 32.8 \\
\hline 5-6 persons & Count & 25 & 13 & 42 & 5 & 105 & 190 \\
& $\%$ & 5.2 & 2.7 & 8.7 & 1.0 & 21.7 & 39.2 \\
\hline More than 6 & Count & 17 & 2 & 27 & 11 & 59 & 116 \\
persons & $\%$ & 3.5 & 0.4 & 5.6 & 2.3 & 12.2 & 23.9 \\
\hline Total & Count & 59 & 27 & 105 & 25 & 269 & 485 \\
& $\%$ & 12.2 & 5.6 & 21.6 & 5.2 & 55.5 & 100.0 \\
\hline
\end{tabular}

Source: Author's Field Survey, 2006. 